\title{
Jean Toomer, Technology, and Race
}

\author{
MARK WHALAN
}

The close relationship between machine technology and the literature of American modernism has long been acknowledged. Indeed, it is hard to imagine Fitzgerald's work without its hyper-materialised cars (and metaphysically potent car crashes), or Dos Passos's USA without the representational possibilities of the camera eye. Other writers in the I 920 s had equally famous fascinations with what cultural producers and critics often abstracted into the concept of "the machine"; William Carlos Williams described poetry as being "machines made of words," and Hart Crane used one of the triumphs of American engineering, the Brooklyn Bridge, as the organising metaphor and structuring principle of his poem The Bridge, identifying his theme as "the conquest of space and knowledge." Of course, writers' fascination with how machinery or technological innovation was effecting social change had not begun with modernism. Yet often goaded by the speed of innovation in the visual arts, some American modernist writers responded to what Cecelia Tichi has called a "gears-and-girders" world by rethinking their relation to time, space, communication and economy with an unprecedented radicalism. And in the I 920 - a decade which saw more cars in Manhattan than in the whole of Britain, Lindbergh's pioneering flight across the Atlantic, and the USA move decisively ahead of Europe in industrial productivity - this rethinking had a particularly pressing urgency. Jean Toomer was one of the writers who participated in this exercise, engaging with European art movements such as Dadaism and Futurism and their proposals for new relations between machine design and literary aesthetics. Yet, as a writer with close links to the Harlem

Mark Whalan is a lecturer in American Literature and Culture at the University of Exeter.

${ }^{1}$ William Carlos Williams, Imaginations, ed. Webster Schott (New York: New Directions, I 97 I), I 5 ; Hart Crane, Letter to Otto Kahn, i 8 Mar. 1926, The Letters of Hart Crane, ed. Brom Weber (Berkeley: University of California Press, 1965), 241. See also Cecilia Tichi, Technology, Literature, Culture in Modernist America (Chapel Hill: University of North Carolina Press, 1987), and Lisa M. Steinman, Science, Technology, and American Modernist Poets (New Haven: Yale University Press, 1987). 
Renaissance, perhaps the most remarkable facet of his thinking about "the machine" was how technology might allow for a new and potentially liberating vision of racial identity within modern America. How the outlines of this vision are evident in his most famous text, Cane, forms the focus of this essay.

In using the term "technology," I hope to preserve the features implied when writers of the time talked about "the machine." Their usage tended to denote instruments and innovations in the mechanical and physical sciences with tangible practical applications, particularly in three areas. The first was machinery's role within industrial production, particularly within the manufacturing industry, a role which was rapidly increasing in the era; indeed, Theodore Kornweibel has estimated that machines displaced 3,272,000 workers within the manufacturing industry between 1920 and 1929. ${ }^{2}$ The second area was the electricity industry; many writers were particularly fascinated by the transformative function of power-houses and dynamos. The third involved developments in communication, particularly the motor car, and new forms of electric communication such as wireless telegraphy, the telephone and the radio. Most uses of the term saw technology as a potent and powerful force which needed to be accommodated or harnessed, but also identified "the machine" as possessing a more abstract type of power which resided in its capacity for radical novelty and innovation.

Toomer's interest in "the machine" gains much significance from the fact that the Harlem Renaissance movement is often seen as at least ambivalent and at most uninterested in technological change. This perception (one of the many tacit factors used to differentiate "modernism" from the Harlem Renaissance within traditional literary histories) is partly due to the complex relationship between increasing technological sophistication and African American employment patterns at the time. If the booming, frequently mechanised industrial sector of the North had facilitated the great migration of black workers from the rural South to the Northern cities, especially during the labour shortages of World War I, it generally persisted in offering them only unskilled work with low job security. Moreover, protective attitudes towards "white jobs" (often underpinned by all-white unions), and white anger at what was perceived to be African Americans' readiness to act as strikebreakers, had contributed to several of the race riots which plagued the country between I9I7 and I9I9. In addition, in several industries, perhaps most notoriously the Chicago stockyards, there was considerable "technological shock" as black migrants used to rural and agricultural employment had to adjust to assembly

2 “An Economic Profile of Black Life in the Twenties," Journal of Black. Studies, 6 (1 976), 307-20, 313 . 
lines and regular working hours. Moreover, the worst jobs with the harshest workplace conditions tended towards hiring a disproportionately high percentage of African American labour. ${ }^{3}$

Perhaps in consequence, African American writers were less keen than some of their white counterparts to aestheticise or abstract their images of "the machine." Such aestheticisation, as Hal Foster notes, involved an "occlusion of the socio-economic bases of technology" which "often distracted from the reality of industrialization." In addition, several African American intellectuals worried that industrial technological development was a product of a white civilisation which would use it to maintain its racial hegemony. Indeed, by 1930 Loren Miller, writing in the African American Journal Opportunity, would be calling the machine "the enemy of the Negro worker," warning that "going into the factory does not destroy the possibility that tomorrow a machine may be invented to throw the Negro back into the streets. "In his critique of the racial inequalities of the US economy in $1920, \mathrm{~W}$. E. B. DuBois cautioned that:

Private ownership of land, tools, and raw materials may at one stage of economic development be a method of stimulating production and one which does not greatly interfere with equitable distribution. When, however, the intricacy and length of technical production increased, the ownership of these things becomes a monopoly, which easily makes the rich richer and the poor poorer. Today, therefore, we are challenging this ownership. ${ }^{6}$

Yet, if DuBois's hopes at this time were pinned on a fusion of socialism and a global collaboration of peoples economically exploited on the basis of race, other African American writers saw a confrontational version of primitivism as a defence against "the enemy of the Negro worker." Claude McKay, for

${ }^{3}$ See James R. Grossman's Land of Hope: Chicago, Black Southerners, and the Great Migration (Chicago: University of Chicago Press, 1989) particularly Chs. 7 and 8, and David Levering Lewis's "We Return Fighting," the first chapter of When Harlem was in Vogue (Oxford: Oxford University Press, I989).

${ }^{4}$ Hal Foster, "Prosthetic Gods," Modernism/Modernity, 4.2 (1997), 5-38, 7.

5 Loren Miller, "The Negro faces the Machine," Opportunity 8 (1930), 297-99, 297, 298. These fears were not groundless; Kornweibel has noted that over a million jobs were made obsolete by technology in the 1920s, and hypothesises that as African American jobs were generally less secure than those of other ethnic groups, "blacks suffered proportionally more from technological unemployment," 3 I 3 .

6 W. E. B. DuBois, "Work and Wealth," Darkwater: Voices from Within the Veil, I920 (Mineola, NY: Dover, I999), 47-59, 57.

7 DuBois's political strategy to this effect was evident in his instigation of the Pan-African congress in Paris in 1919, which purposely ran concurrently with the negotiations at Versailles. See John Hope Franklin and Alfred A. Moss Jr., From Slavery to Freedom: A History of Negro Americans, 6th edn (New York: McGraw-Hill, I988), 304. 
example, saw increasing mechanisation in the workplace as a significant arena of conflict between essentialised racial characteristics: where African spontaneity, creativity and spirituality collided with the white characteristics of method, avarice, authoritarianism and a dehumanising faith in technology. In Banjo, the writer and critic Ray muses:

That this primitive child, this kinky-headed, big-laughing black boy of the world, did not go down under the serried crush of trampling white feet; that he managed to remain on the scene, not worldly-wise, not "getting there," not yet machine-made, nor poor-in-spirit like the regimented creatures of civilization, was baffling to civilized understanding. ${ }^{8}$

This type of defiant proclamation of African American primitivism unsettled many African American intellectuals at the time, as it seemed to dovetail with the stereotypes which American whites so often invoked as reasons for racially discriminative practices. ${ }^{9}$ Moreover, negative assessments of "the machine" were complicated for "race men" such as DuBois by their commitment to a narrative model of progress for the African American population which predicted the "uplift" of an oppressed people. Many things were important as benchmarks of how this progress could be measured - education, increasing professionalisation, artistic production - but the underlying criterion was material. Yet in the i 920 s more and more of the common symbols of material progress were mechanical consumer durables. This raised a dilemma for those such as DuBois, who had based much of their moral authority on a rejection of crude materialism; for as James Baldwin was to ask in I963, "how can one ... dream of power in any other terms than in the symbols of power?"10

Foremost amongst these symbols was the car, and some of the most optimistic African American cultural production of the r920s offers a celebration of the car as a symbol of personal and financial success which had been achieved despite the obstacles of racial oppression: in the broadest sense it frequently stood for the exhilarating achievement of mobility. James Van Der Zee's photograph "Couple in Raccoon Coats" is perhaps the most famous celebration of African American car ownership as a symbol of upward social mobility; but Zora Neale Hurston's trip to Florida in a Chevrolet to gather African American folk material is also well known. Rudolph Fisher's story "Dust" charts a car chase between an African American couple who are

8 Claude McKay, Banjo, i929 (New York: Harvest-Harcourt Brace Janovitch, i 957), 3 I 4.

9 As well as DuBois's famously hostile reaction to McKay's previous novel, Home to Harlem, one white reviewer noted of Banjo that "White authors do not need to write against Negroes anymore ... the Negroes are writing against themselves." Quoted in Levering Lewis, 225 and 239 .

10 James Baldwin, The Fire Next Time, i 963 (Harmondsworth: Penguin, I 970), 70. 
"buzzed" by a car with Georgia plates; stung with offended race pride, the couple give furious chase, which culminates in both cars being forced off the road. The "snapper" ending, of course, is achieved when the driver of the car from Georgia turns out to be black. Even DuBois - in his essay "The Souls of White Folk" - exemplified the irrationality of racial hatred by remembering an occasion when he saw "the upper lip of a quiet, peaceful man curl back in a tigerish snarl of rage because black folk rode by in a motor car."11

Given these ambivalences around "the machine" in African American literature and politics at the time, it is perhaps unsurprising that a writer with less than definite links to the Harlem Renaissance should present one of its most enthusiastic - and aestheticised - responses to machine technology. This was the case with Jean Toomer, who published Cane in 1923. Uncomfortable with the one-drop rule which after the i 920 census categorised anyone with any African ancestry as "Negro," Toomer felt that his tiny percentage of African heredity should not determine his racial identity; he stated that his genealogy made him "an American, neither white nor black." 12 In the early I920s, he moved primarily in white modernist circles, yet was on good terms with African American intellectuals such as Alain Locke and Georgia Douglas Johnson. Largely due to his contacts in the white intellectual community, however, Toomer became engaged in debates about "the machine," and how it might affect racial politics in the United States.

Toomer's interest in this subject was stimulated by his correspondence with the critic Gorham Munson, which began in 1922. Toomer was excited by Munson's manifesto for the little magazine Secession, where Munson had urged the rejection of a duality between "machinery and the values of life," claiming that "the glory of the French dadaists ... rests principally on their endeavour to put Machinery into positive equilibrium with man and nature." 13 The two became friends and Toomer agreed to review Munson's critical work Waldo Frank: A Study, which assessed the fiction and the cultural criticism of their mutual friend. The review appeared in the little magazine $S_{4} N$ which would become the forum for Toomer's most provocative and sustained comments

11 W. E. B. DuBois, “The Souls of White Folk," Darkwater, 17-29, i 9 . These examples also illustrate that, for African American writers, a closely related factor to representations of mechanical technology was the developing urban spaces of African America. Maria Balshaw explores these connections in her fascinating study Looking for Harlem: Urban Aesthetics in African-American Literature (London: Pluto Press, 2000).

12 Jean Toomer, The Wayward and the Seeking: A Collection of Writings by Jean Toomer, ed. Darwin T. Turner (Washington, DC: Howard, University Press, I982), 92-93.

13 Gorham Munson, "The Mechanics for a Literary Secession," $S_{4} N, 22$ (1922), n.p. 
about machinery and aesthetics. ${ }^{\mathbf{1 4}}$ Munson's book on Frank, whilst generally flattering, had criticised Frank's views on industrialism and the potential of machines; he felt that Frank had portrayed the machine as a "necessary evil" which required "anti-bodies to offset its ravages." An alternative, Munson mused, was the position of the Italian Futurist Filippo Tommaso Marinetti, which offered a recognition that "culture must now work out a harmony between three factors, man, nature, and machinery ... we must ... bring the machine within the scope of the human spirit."15 In contrast to Frank, therefore, Munson identified contemporary technology and popular culture as a cause for aesthetic, cultural and national celebration. Frank, he felt:

underestimates certain phenomena of American civilization that may seem most significant and healthy later on, such phenomena as our skyscrapers, bridges, motion pictures, jazz music, vaudeville, electric light displays, advertising. He may have missed completely the peculiar genius of the American people thrusting into a new age. $^{16}$

Toomer's review enthused over Munson's vision of spiritualising machinery, and stressed the personal appeal which this had for his own aesthetics. Elsewhere in $S_{4} N$ he elaborated on his formal attraction to machines, praising as "the only art attitude" the decision to use "modern forms, and not the hurt caused by them, as the basis of the national literature." 17 These "modern forms" were analogous to new mechanical technology, indeed sometimes were identical with them; he enthused that "I neglected the "poetry of the people' for such things as motorcycle motors, dynamos and generators. ... There is not a statue in Washington with the living beauty and line of certain Pierce-Arrow cars. "18 Yet, despite the hollow formalism of some of these statements, which were little more than avant-garde posturing, Toomer was quick to appreciate Munson's caution that duality was a limitation in thinking about human relations to machinery. This anticipates a point made by the contemporary critic Hal Foster, who has talked about the "double logic of

14 A discussion of the editorial policies of Secession and $S_{4} N$ in relation to machine aesthetics is given in Dickran Tashjian's Skyscraper Primitives: Dada and the American Avant-Garde (Middleton, CT: Wesleyan University Press, 1975), Ch. 6. Also useful is Munson's account of the history of Secession, "A Comedy of Exiles," The Literary Review, I2 (1968), 4I-75.

15 Gorham Munson, Waldo Frank: A Study (New York: Boni and Liveright, 1923), 24.

16 Ibid., 25.

17 Jean Toomer, "Open Letter to Gorham Munson, " $S_{4} N, 25$ (March 1923). Rpt. in Jean Toomer: Selected Essays and Literary Criticism, ed. Robert B. Jones (Knoxville: University of Tennessee Press, 1996), I9-20, I9. Perhaps the fullest treatment of Toomer's involvement with "machine aesthetics" and $S_{4} N$ is given in Charles Scruggs's "Textuality and Vision in Jean Toomer's Cane," Journal of the Short Story in English, ro (1 988), 93-I I4.

18 Ibid., 20. 
the prosthesis" in modernist assimilations of machinery into its aesthetics. Foster contends that this double logic established a crippling polarity between the human body and the machine, as "so opposed, the two could only conjoin, ecstatically or tortuously, and technology could only be a 'magnificent' extension of the body or a 'troubled' constriction of it." 'This led to a situation in which "one could only resist technology in the name of a natural body or accelerate it in the search for a postnatural body on its other side."19

Toomer realised this "double logic" would lead to a system of either technophobic rejection of mechanical technology or slavish admiration of its formal principles. Instead, he began to consider models for effacing a dualism between mechanism and organism. He toyed with notions of either "spiritualising" or "fecundating" the machine, but this was rather a lazy attempt at imagining the industrialised landscape within an organicist/Romantic perspective which was already an anachronism. As he later wrote: "BBack to nature,' even if desirable, was no longer possible, because industry had taken nature unto itself. ... whether we wished to or not, we had to go on."20 Ultimately, however, he envisaged the production, circulation and transformation of energy by machinery as an important figure for art in two respects. Firstly, it was suitable for conceptualising the streamlining of the circulation of desire within cultural production, irrespective of racial or political barriers. Secondly, it would serve as an analogue to the transformative energy which underpinned all artistic creativity. This was evident in his plans for a (never completed) novel to follow Cane in I 924, when he conceptualised his main character in the terms of a machine. Toomer imagined him to be:

(I) A generator, making his own qualitative energy.

(2) A transformer, turning the crude energy of his material world into stuff of higher, rarer potency.... As a first and inevitable step in the racial unification of America: negatively, the lack of racial consciousness and self-consciousness; positively, a prescription which includes spiritual, intellectual, emotional states as well as the pleasant (or repulsive) variants of color or feature.... Nothing less than a related and inclusive art-form will satisfy it. American, extra-American, European. Universal? I hope so. ${ }^{21}$

It is significant to note that the result of such mechanical efficiency in the dynamic process of artistic creativity for Toomer is the "racial unification of

${ }^{19}$ Foster, "Prosthetic Gods," 5-6. $\quad 20$ Toomer, Wayward and the Seeking, I 29.

21 "Notes for Novel." n.d. Jean Toomer Papers. Box 48, Folder Ioo2. The James Weldon Johnson Collection. Beinecke Rare Book and Manuscript Library. Citations of material taken from this archival collection will hereafter be footnoted in abbreviated form as JTP. 
America." If it was the energy of the material world that was being transformed, then that material world - or the sense of it as material - could be transformed as well. It is here that Toomer approaches both a recognition of the socially constructed nature of what constitutes materiality, and a theory of artistic agency which can alter the nature of what is perceived as material. The specific form of materiality to be transformed here is race, or at least the view of race as an essentialised materiality, a biological certainty. This transformative machine is one which takes "race consciousness" and converts it into a "related and inclusive art form."

Although this was not fully theorised until later, the relation between race, materiality and aesthetics had been occupying Toomer's mind whilst he was composing Cane, and it was then that he began to discuss it as his "duty" to transform the relation between race and normative standards of beauty. In a letter of I 922 he wrote about what he called the "tyranny of the Anglo-Saxon ideal," describing it as follows:

white skin is the most beautiful and desirable in the world; the minds of white races are superior to those of any other race; the souls of white folk are the chosen of God. ...

Paradoxical as it may seem, we who have Negro blood in our veins, who are culturally and emotionally the most removed from Puritan tradition, are its most tenacious supporters. ... We are suspicious and often ashamed of our emotions.... Such wholesale substitution (I might even say perversion) of ideal must not continue. A beauty that is their own must be revealed to these people. ... Their eyes must open to the charm of soft full lines. Of dusk faces. Of crisp curly hair. ... To do these things is to create a living ideal of one's own.

It is my privilege and duty ... to aid, perhaps in a large measure, to crystallize this ideal. $^{22}$

In Cane Toomer showed he was well aware of the social ramifications of a "tyrannical" system of aesthetics which debased the black body. In "Kabnis," the final section of Cane, the ex-slave, Father John, exemplifies the results of such aesthetic and racial "tyranny." John lives in the basement of a Southern workshop, and terrifies the light-complexioned, Northern intellectual Kabnis, whom many commentators have taken to be an alter ego for Toomer. Father John is described as like a "bust in black walnut," a phrase which draws attention to the aesthetic constructedness of the body; it is sculpted rather than "natural." "23 Yet, later, Kabnis taunts him with the accusation that "you

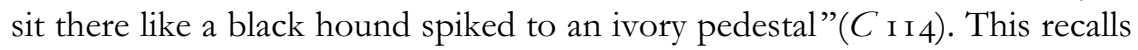
the thesis of Allon White and Peter Stallybrass in The Politics and Poetics of

22 Toomer to Mae Wright, 4 Aug. I922. JTP Box 9, Folder 283.

${ }^{23}$ Jean Toomer, Cane, 1923, ed. Darwin T. Turner (New York: Norton, 1988), 106. All further references to this edition will be cited parenthetically in the text as $C$. 
Transgression, that social organisation is defined by a series of hierarchies in which the "low" has a symbolical force in the constitution of a hierarchy which is just as important as the "high." As they suggest, it is the "vertical extremities" of any hierarchy which "frame all further discursive elaborations. "24 In terms of the way in which bodies are constituted into social relations, they rely on Bakhtin's opposition between the "classical" and the "grotesque" body to provide the polarities of their hierarchical spectrum. In connection to Cane, therefore, it is clear that the debased - or grotesque black body is equally as significant for establishing the whiteness of beauty as are "classical" white icons, hence the ironic fact that Father John's body is placed on a pedestal. Yet this hierarchy of bodies, which structures racial imagery, is kept in place by violence; Father John is "spiked" to the pedestal. Toomer thus suggests that the "grotesqueness" of Father John is reliant on being brutally "spiked" into a system where antiblack violence serves to continually debase black bodies, and thus legitimate further violence and oppression against them because of their debased condition. Elsewhere in Cane, Toomer illustrated his awareness that the ritual of lynching helped to produce the racial categories of both whiteness and blackness; the white woman in "Portrait in Georgia," for example, is "white as the ash / Of black flesh after flame" (C 29). As Walter Benn Michaels notes, "black flesh is burned in order to make a white body. What begins as a narrative of the attempt to preserve racial difference turns out to be a narrative of the origins of racial difference. "25

Toomer saw technology as offering a way out of this closed circuit of aesthetics, oppression and violence within the rural South. By largely ignoring the impact upon African Americans of machinery in the workplace, which had generated much ambivalence about technology amongst African American writers, Toomer had a freedom to speculate on how technology's twin attributes of power and radical novelty might be useful in reconceptualising the increasingly inflexible categorisation of race within the United States. This is evident in much of the second section of Cane, but is perhaps best illustrated in the poem "Her Lips are Copper Wire." Toomer sent this poem to Norman Fitts, the editor of $S_{4} N$, in early i 923 . Fitts responded so enthusiastically to the poem that he translated it into Italian and sent it to the leader of the Italian Futurist movement, Filippo Tommaso Marinetti, telling him that it represented "one of the first attempts to write machinery poetry" in the United

24 Peter Stallybrass and Allon White, The Politics and Poetics of Transgression (Methuen: London, I986), 3 .

${ }^{25}$ Walter Benn Michaels, Our America: Nativism, Modernism, and Pluralism (Durham, NC: Duke University Press, I 995), 62. 
States. ${ }^{26}$ The poem was published in the May-August number of $S_{\mathbf{4}} N$, along with Fitts's translation of Marinetti's "Futurism," one of his many manifestoes of the movement. The manifesto praised dynamism, speed and electricity, and found that there was "Nothing ... more beautiful than a great humming powerhouse," which is one of the key images in Toomer's poem. ${ }^{27}$

As Tim Armstrong has noted: "Modernist texts are electrical, plugging into a scientific rhetoric which channels flows of energy and information." Toomer's poem suggests that electrical power offers just such a model of reimagining forms of communication; notably, the only moment of mutually rewarding sexual communion and communication in Cane is given in this poem. Using the metaphor of electricity to suggest the polarities of heterosexual desire, the two bodies of the poem are metaphorically transformed into an electrical circuit of wire and lightbulb. When the circuit is completed, allowing for the unimpeded transmission of desire, the light of sexual communion is activated; "with your tongue remove the tape / and press your lips to mine / till they are incandescent" $(C$ 57). Metaphorically transformed into this new technology, the black body gains a freedom that the "black hound spiked to an ivory pedestal," the Southern, rural body of the ex-slave Father John in "Kabnis," could never have. It becomes powerful, capable of communication ("telephone the power-house / that the main wires are insulate") and "incandescent" ( $C$ 57). This is in contrast to the enforced muteness of the ex-slave Father John, whose inability to speak forms a central feature of "Kabnis." As such the bodies in "Her Lips are Copper Wire" achieve a liberatory form of interpersonal communion, and freedom from white discursive structures of the black body, achieved through the new communicative possibilities of technology.

The metaphor of the electrical generator is also used in other sections of Cane. Yet, rather than the circuitry of desire evident in "Her Lips are Copper Wire," the transformation of mechanical power into electricity is used as a metaphor for violent social change in a key moment in the story "Box Seat." In this narrative, the protagonist, Dan, is seated in the all-black Lincoln Theatre, an institution frequented by the black middle classes of Washington.

${ }^{26}$ Norman Fitts to Jean Toomer, Good Friday 1923. JTP Box 3, Folder 79.

${ }^{27}$ Filippo Tommaso Marinetti, "Futurism," trans. Norman Fitts, $S_{4} N$, $26-9$ (1923), n.p. Toomer also wrote several "sound-poems," which are very similar to Marinetti's theory of Parole en Liberta (or "Words in Freedom"), and Hugo Ball's Dadaist sound poems. See The Collected Poems of Jean Toomer, ed. Robert B. Jones and Margery Latimer Toomer (Chapel Hill, NC: University of North Carolina Press, i 988), i 5-16.

28 Tim Armstrong, Modernism, Technology and the Body: A Cultural Study (Cambridge: Cambridge University Press, I998), I 9 . 
Furious at the class and race exclusions he sees around him, he dreams about destroying the building, and by extension the social and racial architecture which he feels so oppressed by:

I am going to reach up and grab the girders of this building and pull them down. The crash will be a signal. Hid by the smoke and dust Dan Moore will arise. In his right hand will be a dynamo. In his left, a god's face that will flash white light from ebony. (C 68)

A dynamo is a machine for converting mechanical energy into electric power, and here it is the dynamo which "powers" the light emerging from a black god. As many black intellectuals of the time realised, and as Richard Dyer has shown, the "whitening" of Jesus in Western representation was linked to an emergent discourse of racial difference and hierarchy, the result of which was the solidification of a politics of white supremacy. Accordingly, depictions of a black Christ or a black Mary were not uncommon in the cultural production of the Harlem Renaissance. ${ }^{29}$ Here, Toomer's ebony faced god assaults the aesthetic norms of his society, effecting a challenging black appropriation of deity which protests the "tyranny of the Anglo-Saxon ideal." Yet this appropriation is possible only with the energy of the dynamo, the transformative mechanism which converts his resentment into the focused action of resistance.

Dan's fantasy of destroying Lincoln Theatre is a moment similar to those which Peter Nicholls has identified as typical of Italian Futurism, in that "the Futurists knew only those beginnings in which the self emerges new-born, without father, mother, past." Yet it must be noted that Toomer's fantasies of regenerative destruction could move disturbingly close to the misogynistic and belligerent rhetoric for which Marinetti is infamous. This is implicit in Toomer's gendering of Dan's violent reaction to the status quo; a significant reason for Dan's fury is the inability of his sometime girlfriend, Muriel, to cast off bourgeois morality and taste. ${ }^{30}$ Similar to the Futurists, then, this violence seems rooted in a belief that "the feminine denotes a particular psychological formation which is in some sense resistant to the new," and which therefore serves as a significant limitation to the inclusiveness of Toomer's liberatory fantasies of technologically enabled protest. ${ }^{31}$

${ }^{29}$ Richard Dyer, White (London: Routledge, I997), 68. Elsewhere in Cane, “an inspired Negress, of wide reputation for being sanctified, drew a portrait of a black Madonna on the courthouse wall" (23). DuBois drew on the motif of the black Christ in his "The Second Coming," printed in Darkwater; Winold Reiss included a portrait of the black Madonna in The New Negro (1925); Countee Cullen titled his 1929 book of poems The Black. Christ.

${ }^{30}$ Peter Nicholls, Modernisms: A Literary Guide (Basingstoke: Macmillan, i 995), 85-86.

31 Ibid., 88. 
Notwithstanding this, as well as the transformative potentialities which technology offered to racial hierarchies of the body, Toomer also considered the effect of new technologies of transport and communication upon social space. Social relations conceptualised according to networks of modern communication technology, rather than organic models of communal integration, was an idea that Toomer had observed in Munson's Waldo Frank: $A$ Study. Of particular interest to him were the comments on Waldo Frank's I 922 novel City Block which focused on the concept of unanimisme. This idea had been developed by the French writer Jules Romains: he saw modern urban life as a harmonious rhythmic system in which the bodily rhythms of the population and the rhythms of the mechanised city became synchronised, melding the entire environment into what he called a holistic "unanime."32 This epiphanic urban conglomeration reconfigured both the body and social space, as Romains explained:

Society, categories, classes, "le monde," "le demimonde," "le peuple," abstractions; collective words that designate no collective being. Nothing of all that has concrete existence, and therefore nothing of it will last.... What exists, what is beginning to exist with a complete, bodily, conscious life, are groups; streets, city squares, meeting halls, theatres. These are the beings that have a future. ${ }^{33}$

The rhythm of the unanime was largely determined by urban traffic patterns; Romains's first experience of a unanime came during rush hour, when the "wheel of the omnibus that gives sparks ... [gave] a rhythm to my impersonal thought." ${ }^{34}$ Within the experience of a unanime, therefore, technology's interaction with urban space provided the potential of liberation from social divisions and categorisations through the erasure of the boundary between organic and inorganic entities. Frank, a good friend of Romains's, was unsure about the applicability of the concept to City Block, but that did not stop Munson and others seeing the possibilities of unanimisme in Frank's work as one of its most interesting features. As well as Munson's exploration of this in the Study, a special Waldo Frank edition of $S_{4} N$ printed in January 1924 featured two articles assessing Frank's relation to unanimisme. ${ }^{35}$

32 Rosalind Williams, "Jules Romains, Unanimisme, and the Poetics of Urban Systems," Literature and Technology, Research in Technology Studies, Vol. 5, eds. Mark L. Greenberg and Lance Schachterle (London: Associated University Presses, I992), 177-205, 179.

33 Ibid., I93. 34 Ibid., I90.

35 Assessments of Frank's involvement with this concept can be found in Casey Nelson Blake's Beloved Community: The Cultural Criticism of Randolph Bourne, Van Wyck, Brooks, Waldo Frank and Lewis Mumford (Chapel Hill: University of North Carolina Press, 1990), 145-47; and also in Charles Scruggs and Lee VanDemarr's Jean Toomer and the Terrors of American History (Philadelphia: University of Pennsylvania Press, I998), 79-80. 
Such ideas are evident in Cane's second section, the bulk of which Toomer wrote during his most intensive period of contact with Waldo Frank, and which he set in Washington DC and Chicago. ${ }^{\mathbf{3 6}}$ From the outset, networks formed by the transformative technologies of modernity suggest radical possibilities for African American organisation, community and subjectivities. In "Seventh Street," for example, the rhythm of the "Ballooned, zooming Cadillacs / Whizzing, whizzing down the streetcar tracks" provides the tempo for this vignette of the main street in the African American district of Washington $\left(C_{4} \mathrm{I}\right)$. The lines, part of a repeated stanza of verse, appear before and after the main prose-poetry section of the piece, and represent a framing, organisational force for the community. Just as in Romains's initial unanime, the convergence of the rhythm of mechanised transport and the rhythm of thought suggests a symbiotic connection between poet, populace and a technological, urban milieu. Moreover, the vitality of the unanime is specifically focused and directed, as the energies of African American modernity target the edifices of an outdated racial architecture; the Street will destroy the "whitewashed wood," the "stale soggy wood" of white hegemony in Washington ( $\left.C_{4} \mathrm{I}\right)$.

Within Cane, therefore, modern technology provides metaphors of communication, and forms of social interaction, which can redress racial injustice; it also provides the dynamic process whereby the desire for reform of America's oppressive racial politics becomes transformed into action. At the centre of this exists the figure of the artist, transforming through a process of mechanical efficiency material forms which degrade or oppress into forms which offer liberation and agency. This metaphor occupied a central place in Toomer's visionary outline of a racially unified America, an America which could only exist after the "tyranny of the Anglo Saxon ideal" had been broken. Yet it is worthwhile concluding by mentioning that his most extended vision of this occurred in a New Jersey shipyard, which kept its workers de-unionized and demoralized - a job in which Toomer lasted only ten days. Yet it was there that he used to look at the cranes and fantasise about how their potential could apply to him:

I used to lift my head from work to see a slender crane lifting and carrying with precision some huge bulk - and I was thrilled and fascinated, thrilled aesthetically by the purity and perfect functioning of that slender arm as delicate as an etching and yet so powerful. So, I told myself, so a perfect mind might lift the bulk of knowledge and deposit it for mankind to build a world. ${ }^{37}$

${ }^{36}$ For the most detailed assessment of Toomer's personal and literary involvements during the period of composition of Cane, see Scruggs and VanDemarr, Ch. 5 - "Writing Cane."

37 Untitled Autobiography. JTP, Box 22, Folder 560. 
He wrote that this made him "happy as the artist is happy who sees the beauty of forms and visions to the exclusion of human actual conditions." Technology may have offered paradigms of form, metaphors for transformation, efficiency and power, but it was not a mode of immediate redress for "human actual conditions." Technology could only offer metaphor or ideal, and not practical solutions to the politics of racial discrimination and exclusion. As such, this gives a foreshadowing of Toomer's drift into idealist philosophy which occurred after his exposure to the teachings of the Armenian mystic Georges Gurdjieff in I 924. Nonetheless, in questioning what made somebody both human and actual, Toomer's consideration of the technological played a highly significant role in his subtle critique of American racial politics. 